\title{
Implementasi Program Parenting bagi Orang Tua Siswa di PAUD Al-Akram Desa Sepapan Kabupaten Lombok Timur
}

\author{
Suharyani*, Ni Ketut Alit Suarti, I Wayan Tamba, \\ I Made Gunawan, Farida Herna Astuti \\ Fakultas Ilmu Pendidikan dan Psikologi (FIPP) Universitas Pendidikan Mandalika \\ *Corresponding Author: suharyani@ikipmataram.ac.id
}

\begin{abstract}
The purpose of this community service program is to assist the managers and teachers of PAUD Al Akram in maximizing 6 aspects of child development, namely aspects of religious and moral values, physical and motoric aspects, cognitive aspects, social emotional aspects, language aspects and art aspects found in students. through the implementation of parenting programs for parents. This service method uses mentoring and counseling with the target being the managers and teachers of PAUD Al-Akram. The result of this service program is that after 6 months of mentoring to managers and teachers, Al Akram PAUD already has a routine schedule of once every 2 weeks for parenting activities for parents of students with parenting material plans that are quite systematic and structured using a learning approach. adults and according to the character of the local community.
\end{abstract}

Abstrak: Tujuan program pengabdian kepada masyarakat ini dalah untuk mendampingi pengelola dan guru PAUD Al Akram dalam memaksimalkan 6 aspek perkembangan anak yaitu aspek nilai Agama dan Moral, aspek fisik dan motoric, aspek kognitif, aspek sosial emosional, aspek bahasa dan aspek seni yang terdapat pada anak didik melalui pelaksanaan program parenting bagi orang tua. Metode pengabdian ini menggunakan pendampingan dan penyluhan dengan sasaran adalah pengelola dan guru PAUD Al-Akram. Hasil program pengabdian ini yakni setelah dilakukan pendampingan selama 6 bulan terhadap pengelola dan guru, PAUD Al Akram sudah memiliki jadwal secara rutin 2 minggu sekali untuk kegiatan parenting kepada orang tua siswa dengan rencana materi-materi parenting yang sudah cukup sistematis dan terstruktur dengan menggunakan pendekatan pembelajaran orang dewasa serta sesuai dengan karakter masyarakat setempat.
Article History:

Received: 12-03-2021

Reviewed: 19-04-2021

Accepted: 24-04-2021

Published: 05-05-2021

Key Words:

Parenting Program,

PAUD.

Sejarah Artikel:

Diterima: 12-03-2021

Direview: 19-04-2021

Disetujui: 24-04-2021

Diterbitkan: 05-05-2021

\section{Kata Kunci:}

Program Parenting, PAUD.

How to Cite: Suharyani, S., Alit Suarti, N., Tamba, I., Gunawan, I., \& Astuti, F. (2021). Implementasi Program Parenting bagi Orang Tua Siswa di PAUD Al-Akram Desa Sepapan Kabupaten Lombok Timur. Jurnal Pengabdian UNDIKMA, 2(1), 83-90. doi:https://doi.org/10.33394/jpu.v2i1.3729

doi:https://doi.org/10.33394/jpu.v2i1.3729

This is an open-access article under the CC-BY-SA License.

\section{Pendahuluan}

Pendidikan nonformal yang termaktub dalam Undang-Undang nomor 20 tahun 2003 tentang Sistem Pendidikan nasional menyebutkan bahwa Pendidikan nonformal diselenggarakan bagi warga masyarakat yang memerlukan layanan pendidikan yang berfungsi sebagai pengganti, penambah, dan/atau pelengkap pendidikan formal dalam rangka mendukung pendidikan sepanjang hayat. Pendidikan nonformal berfungsi mengembangkan potensi peserta didik dengan penekanan pada penguasaan pengetahuan dan keterampilan fungsional serta pengembangan sikap dan kepribadian profesional. Salah satu jenis program pendidikan yang diselenggarakan dalam pendidikan nonformal adalah pendidikan anak usia dini (PAUD). 
Pendidikan Anak Usia Dini (PAUD) adalah jenjang pendidikan sebelum jenjang pendidikan dasar yang merupakan suatu upaya pembinaan yang ditujukan bagi anak sejak lahir sampai dengan usia enam tahun yang dilakukan melalui pemberian rangsangan pendidikan untuk membantu pertumbuhan dan perkembangan jasmani dan rohani agar anak memiliki kesiapan dalam memasuki pendidikan lebih lanjut yang diselenggarakan pada jalur formal, nonformal dan informal. Pemberian rangsangan pada anak usia dini tidak hanya membutuhkan peran tutor saja, akan tetapi peran dan pola asuh orang tua dalam keluarga sangat dibutuhkan demi mencapai tumbuh kembang anak yang optimal, salah satunya adalah melalui kegiatan parenting.

Pola asuh merupakan bagian dari proses pemeliharaan anak dengan menggunakan teknik dan metode yang menitikberatkan pada kasih saying dan ketulusan cinta yang mendalam dari orang tua. Pola asuh tidak akan terlepas dari adanya sebuah keluarga. Keluarga merupakan suatu kesatuan kekerabatan yang juga merupakan satuan tempat tinggal yang ditandai oleh adanya kerjasama ekonomi dan dan mempunyai fungsi untuk melanjutkan keturunan sampai mendidik dan membesarkannya (Wijaya dalam Darokah dan Safaria, 2005 dalam Muhammad Takdir Ilahi, 2013)

Abdullah Nashih Ulwan membagi tanggung jawab orang tua dalam mendidik bersentuhan langsung dengan pendidikan Iman, pendidikan moral, pendidikan fisik, pendidikan rasio/akal, pendidikan kejiwaan, pendidikan social dan pendidikan seksual. Konteksnya dengan tanggung jawab orang tua dalam pendidikan, maka orang tua adalah pendidik yang pertama dan utama dalam keluarga. (Syaiful Bahri Djamarah, 2004).

Peran utama yang dapat dilakukan orang tua dalam mengembangkan karakter anak. Pertama, berkewajiban menciptakan suasana yang hangat dan tentram. Tanpa ketentraman, akan sukar bagi anak untuk belajar apa pun dan anak akan mengalami hambatan dalam pertumbuhan jiwanya. Ketegangan dan ketakutan adalah wadah yang buruk bagi perkembangan karakter anak.Kedua, menjadi panutan yang positif bagi anak sebab anak belajar terbanya dari apa yang dilihatnya, bukan dari apa yang didengarnya. Karakter orang tua yang dierlihatkan melalui perilaku nyata merupakan bahan pelajaran yang akan diserap anak. Ketiga, mendidik anak artinya mengajarkan karakter yang baik dan mendisiplinkan anak agar berperilaku sesuai dengan apa yang telah diajarkannya. (Gunadi, 2008: M. dalam Amini, 2008)

Program parenting yang menjadi salah satu program dalam penguatan kehidupan keluarga dan masyarakat Indonesia, memberikan salah satu penguatan dalam kehidupan masyarakat, terutama perkembangan anak usia dini, metode pengasuhan dan pola komunikasi yang dijalankan oleh sebagian besar masyarakat. Pendekatan yang tepat dalam pendidikan keluarga diharapkan memberikan hasil berupa penguatan untuk aksesibilitas masyarakat untuk peningkatan kualitas kehidupan melalui penguatan keluarga. Tidak hanya menggunakan pendekatan ekonomi, melainkan dengan menggunakan pendekatan pendidikan yang diharapkan jauh lebih mampu membentuk karakter masyarakat Indonesia ke depan.

Pengembangan program parenting menjadi salah satu metode dalam membangun karakter kehidupan yang ada di tengah masyarakat global. Karena kualitas hubungan keluarga menjadi salah satu unsur penting dalam membangun masyarakat yang saling mendukung satu sama lain. Dengan adanya paradigma pembangunan berkelanjutan menjadi salah satu indikator utama pembangunan masyarakat saat ini, maka salah satu upaya yang dilakukan adalah dengan mengembangkan serangkaian kegiatan yang secara konsisten dilakukan untuk mengubah, membangun paradigma masyarakat mengenai konteks kualitas kehidupan yang harus dilakukan, sehingga dapat memberikan nilai tambah bagi kehidupan 
masyarakat itu sendiri. Termasuk mengenai program keayahbundaan yang diharapkan dapat memberikan warna baru dalam peningkatan kualitas kehidupan masyarakat terutama proses pendampingan dan membangun kesadaran pendidikan keluarga sebagai komponen utama dalam pembangunan masyarakat.

Parenting merupakan upaya pendidikan yang dilaksanakan oleh keluarga dengan memanfaatkan sumber-sumber yang tersedia dalam keluarga dan lingkungan yang berbentuk kegiatan belajar secara mandiri. Parenting sebagai proses interaksi berkelanjutan antara orang tua dan anak-anak mereka yang meliputi aktivitas-aktivitas sebagai berikut: memberi makan (nourishing), memberi petunjuk (guiding), dan melindungi (protecting) anak-anak ketika mereka tumbuh dan berkembang.

Di PAUD Al-Akram belum memiliki jadwal yang rutin untuk pelaksanaan kegiatan parenting, hanya sifatnya temporer saja yaitu ketika ada kegiatan-kegiatan tasyakkuran kelulusan siswa dan pada agenda-agenda rapat orang tua dalam agenda pengembangan lembaga ke depan baru diselipkan kegiatan parentingnya. Adapun materi yang disampaikan juga hanya sebatas pengasuhan anak sangat umum saja karena yang menjadi nara sumbernya adalah pengelolanya yang pengetahuannya tentang parenting masih sangat terbatas.

Sementara pengetahuan orang tua tentang pengasuhan maupun tumbuh kembang anak usia dini sangat terbatas disebabkan karena tingkat pendidikannya yang rata-rata lulus Sekolah Dasar dan bahkan banyak diantaranya yang tidak pernah mengenyam pendidikan baik di sekolah formal maupun nonformal. Demikian pula dengan mata pencaharian mereka yang rata-rata petani dan ibu rumah tangga.Akan tetapi salah satu potensi yang dimiliki adalah keinginan yang kuat untuk melihat anak-anaknya menjadi orang yang berhasil baik di bidang pendidikan secara umum maupun di bidang keagamaan.Atas dasar inilah kami ingin melakukan kegiatan pengabdian kepada masyarakat di PAUD Al-Akram.

Dari permasalahan di atas, maka solusi yang telah dilakukan adalah dengan melakukan pendampingan kepada pengelola PAUD dan guru-guru secara berkala yaitu 2 bulan sekali selama 6 bulan untuk memberikan penguatan-penguatan seputar metode penyampaian maupun materi-materi parenting standar yang perlu diberikan kepada orang tua siswa untuk membantu guru dalam memaksimalkan 6 aspek perkembangan anak yaitu aspek nilai Agama dan Moral, aspek fisik dan motoric, aspek kognitif, aspek social emosional, aspek bahasa dan aspek seni yang terdapat pada anak didik di PAUD Al-Akram. Kami telah menyarankan kepada pengelola dan guru agar membuat jadwal secara rutin untuk kegiatan parenting kepada orang tua siswa dengan penyampaian materi-materi parenting secara sistematis dan terstruktur dengan menggunakan pendekatan yang sesuai dengan karakter masyarakat yang ada di desa Sepapan desa Jerowaru. Disamping itu kami juga kami berusaha untuk memberikan penyuluhan secara langsung kepada orang tua siswa tentang parenting dengan tetap mengedepankan prinsip-prinsip pendidikan orang dewasa.

\section{Metode Pengabdian}

Metode pelaksanaan kegiatan pengabdian ini adalah dengan metode pendampingan yang diberikan kepada Pengelola dan guru-guru PAUD Al-Akram, metode pendampingan ini digunakan dengan pendekatan partisipatif (Rizka \& Tamba, 2019; Sri et al. 2016), selain dengan pendampingan juga menggunakan metode penyuluhan materi yang diberikan bagi orang tua siswa. Kegiatan pengabdian ini telah dilaksanakan selama 6 bulan yang terbagi dalam tiga tahap yaitu: (1) tahap perencanaan, (2) tahap pelaksanaan, (3) tahap evaluasi. 


\section{Hasil Pengabdian dan Pembahasan}

Program pengabdian kepada masyarakat ini dilaksanakan di PAUD Al-Akram desa Sepapan, Kecamatan Jerowaru Kabupaten Lombok Timur. Pada tahap pelaksanaan, telah dilakukan kegiatan pendampingan kepada pengelola dan guru tentang pentingnya program parenting bagi orang tua siswa dalam membantu memaksimalkan perkembangan potensi yang terdapat pada anak usia dini. Tahap pelaksanaan ini telah dilakukan selama 6 bulan dengan intensitas kegiatan pembinaan setiap 2 bulan sekali yang dalam pelaksanaannya dibantu oleh mahasiswa UNDIKMA program Studi PLS yang sekaligus menjadi guru di PAUD Al-Akram yang terlibat dalam program pengabdian kepada masyarakat. Dan dilanjutkan dengan penyajian materi parenting secara langsung kepada ibu-ibu wali murid PAUD Al-Akram selama 1 hari untuk menambah pengetahuan dan wawasan orang tua siswa tentang pola asuh yang baik dalam mendidik anak-anaknya.

Adapun tahapan-tahapan dalam pelaksanaan kegiatannya penyuluhan tersebut adalah sebagai berikut : (1). Ceramah digunakan untuk menyampaikan pengetahuan secara umum tentang program parenting dan pendekatan yang dapat digunakan dalam pendidikan keluarga. (2). Demontrasi digunakan untuk memberikan keterampilan langsung mengenai proses penanganan yang berkaitan dengan permasalahan yang dihadapi oleh anak baik dalam kehidupan personal, interpresonal maupun dalam kehidupan sosial di tengah masyarakat. (3). Tanya jawab digunakan untuk melengkapi hal-hal yang belum terakomodasi oleh kedua metode diatas. (4). Simulasi kegiatan diskusi dan konseling penanganan permasalahan anak dan orang tua yang ada di dalam keluarga masing-masing.

Pada tahap evaluasi dilakukan untuk melihat efektifitas pelaksanaan program Parenting ini dalam mengembangkan 6 aspek perkembangan anak dan sinergisitas antara pola asuh yang dilakukan oleh orang tua dengan stimulan-stimulan yang diberikan oleh guru untuk merangsang perkembangan 6 aspek tersebut pada anak didiknya. Hasil evaluai menunjukkan bahwa setelah dilakukan pendampingan selama 6 bulan terhadap pengelola dan guru, PAUD Al Akram sudah memiliki jadwal secara rutin 2 minggu sekali untuk kegiatan parenting kepada orang tua siswa dengan rencana materi-materi parenting yang sudah cukup sistematis dan terstruktur dengan menggunakan pendekatan pembelajaran orang dewasa serta sesuai dengan karakter masyarakat setempat.

Adapun pembahasan terhadap materi penyuluan parenting kepada orang tua siswa PAUD Al-Akram ini adalah sebagai berikut.

\section{1) Gender dan Gaya Pengasuhan Anak}

Orang tua mungkin tidak menyadari, sebenarnya gaya Pengasuhan antara ayah dan ibu berbeda. Hal ini dikarenakan pada dasarnya gender laki-laki dan perempuan berbeda, baik dalam pola kehidupan, latar belakang maupun pekerjaannya. Perbedaan pada gaya pengasuhan ayah dan ibu sangat wajar, mengingat pada pria, secara fisik memang lebih kuat dari wanita. Selain itu, secara umum pria adalah pencari nafkah dan menyediakan kebutuhan dasar dalam keluarga. Ayah lebih kepada membangun visi dan misi, dan menumbuhkan kompetensi dan percaya diri. Ibu lebih kepada memberikan kasih sayang, sentuhan, memeluk. pada dasarnya gender laki-laki dan perempuan berbeda, baik dalam pola kehidupan, latar belakang maupun pekerjaannya. Perbedaan pada gaya pengasuhan ayah dan ibu sangat wajar, mengingat pada pria, secara fisik memang lebih kuat dari wanita. Selain itu, secara umum pria adalah pencari nafkah dan menyediakan kebutuhan dasar dalam keluarga. Ayah lebih kepada membangun visi dan misi, dan menumbuhkan kompetensi dan percaya diri. Ibu lebih kepada memberikan kasih sayang, sentuhan, memeluk. 
Ibu berkonsentrasi pada kewajban menjaga rumah dan membesarkan anak. Ibu menjadi pengasuh utama pada masa bayi dan ayah berasumsi tidak mempunyai tanggung jawab untuk merawat dan mengasuh bayi. Studi yang dilakukan Sputa \& Paulson (dalam Santrock, 2003) mengatakan bahwa ibu lebih terlibat dalan pengasuhan dibandingkan dengan ayah. Para ibu melakukan jauh lebih banyak pekerjaan rumah tangga daripada ayah. Walaupn ada pria yang melakukan pekerjaan rumah tangga sebanyak yang dilakukan istri, namun berdasarkan hasil studi hal itu hanya sekitar 10 persen saja (Berk, dalam Santrock 2003). Peran ayah sama pentingnya dengan peran ibu dan memiliki pengaruh pada perkembangan anak walau pada umumnya menghabiskan waktu relative lebih sedikit dengan anak dibandingkan dengan ibu. Ayah dikaitkan dengan lingkungan luar keluarga. Interaksi dengan ayah cenderung melibatkan permainan yang bersifat fisik (Santrock, 2013).

Figur seorang ayah memegang peranan penting tidak hanya sekadar mencari nafkah untuk keluarga, tetapi juga berkaitan dengan gaya pengasuhan dan perkembangan anak. Disamping itu, ayah juga memainkan peranan sebagai provider (penyedia dan pemberi fasilitas), protector (pemberi perlindungan), decision maker (pembuat keputusan), child specialiser and educator (pendidik dan yang menjadikan anak sosial), dan nurtured mother (pendamping ibu).

Beberapa penelitian mengungkapkan bahwa adanya perbedaan persepsi dari masyarakat Indonesia dalam menggambarkan peran ayah dan ibu. Ayah dipersepsikan bertanggung jawab untuk pemenuhan urusan keuangan keluarga. Adapun urusan pengasuhan dan pendidikan anak lebih banyak dipegang oleh ibu, tugas-tugas pengasuhan dianggap sebagai kewajiban alami seorang ibu. Sementara itu peran ayah, adalah: (a) menumbuhkan rasa percaya diri dan kompeten pada anak melalui kegiatan bermain yang lebih kasar dan melibatkan fisik baik dalam maupun di luar ruang. (b) menumbuhkan kebutuhan akan hasrat berprestasi pada anak melalui kegiatan mengenalkan anak tentang berbagai kisah tentang cita-cita, (c) mengajarkan tentang peran jenis kelamin laki-laki, tentang bagaimana harus bertindak sebagai laki-laki, dan apa yang diharapkan oleh lingkungan sosial dari laki-laki.

\section{2) Gaya Pengasuhan (Parenting) sesuai Perkembangan Usia}

Peran orang tua dalam pengasuhan anak berubah seiring pertumbuhan dan perkembangan anak. Maka, diharapkan orang tua dapat memahami fase-fase perkembangan anak dan dapat mengimbanginya. Seorang anak perlu melakukan aksiaksi terhadap lingkungannya agar dapat mengembangkan cara pandang yang kompleks dan cerdas atas setiap pengalamannya. Salah satu tugas orang tua pun adalah member pengalaman yang dibutuhkan oleh anak. Oleh karena itu berbagi peranlah dengan baik antara ayah dan ibu, agar kecerdasan dan perkembangan anak dapat berkembang dengan baik dan sempurna.

Melalui parenting yang baik diharapkan dapat mengembangkan anak dengan kepribadian yang baik pula. Kebanyakan orang tua mempelajari praktik pengasuhan dari orang tua mereka sendiri. Sebagian praktik tersebut mereka terima, namun sebagian lagi mereka tinggalkan. Suami dan istri mungkin saja membawa pandangan yang berbeda mengenai pengasuhan (Santrok, 2007).

Orang tua meskipun sama-sama memiliki fungsi pengasuhan terhadap anak, namun peran ortu dalam pengasuhan ini berbeda. Peran ibu, yaitu : (a) menumbuhkan perasaan mencintai dan mengasihi pada anak melalui interaksi, (b) menumbuhkan kemampuan berbahasa pada anak melalui kegiatan-kegiatan, (c) bercerita dan 
mendongeng, serta melalui kegiatan yang lebih dekat dengan anak, yakni berbicara dari hati ke hati kepada anak, (d) mengajarkan tentang peran jenis kelamin perempuan, tentang bagaimana harus bertindak sebagai perempuan, dan apa yang diharapkan oleh lingkungan sosial dari seorang perempuan. Sementara itu peran ayah, adalah: (a) menumbuhkan rasa percaya diri dan kompeten pada anak melalui kegiatan bermain yang lebih kasar dan melibatkan fisik baik di dalam maupun di luar ruang. (b) menumbuhkan kebutuhan akan hasrat berprestasi pada anak melalui kegiatan mengenalkan anak tentang berbagai kisah tentang cita-cita, (c) mengajarkan tentang peran jenis kelamin laki-laki, tentang bagaimana harus bertindak sebagai laki- laki, dan apa yang diharapkan oleh lingkungan sosial dari laki-laki.

Perbedaan peran antara ayah dan ibu dalam pengasuhan juga dikemukakan oleh Gunarsa (2008) yang mengatakan, peran ibu adalah memenuhi kebutuhan fisiologis dan psikis, memberi contoh dan teladan, sebagai manager yang bijaksana, merawat dan mengurus keluarga dengan sabar, sebagai pendidik yang mengatur anak. Peran ayah adalah pencari nafkah, memberi rasa aman, berpartisipasi dalam pendidikan anak, dan sebagai pelindung yang tegas.

Pada masyarakat modern, dimana semua kebutuhan semakin banyak dan semakin mahal menuntut orang tua harus mencari cara untuk terus bertahan. Salah satunya dengan bekerja, dimana dulu hanya suami atau ayah saja yang bekerja, sekarang istri atau ibu juga bekerja. Hal ini berdampak pada gaya pengasuhan orang tua terhadap anak. Orang tua yang keduanya bekerja dapat mencukupi kebutuhan keluarga, bahkan lebih. Namun dengan bekerja, waktu yang diperlukan untuk mengasuh anak jadi terbatas, karena sebagian waktu digunakan untuk bekerja. ketika orangtua bekerja, anak dimasukkan ke sekolah atau tempat penitipan anak jika mempunyai anak anak pada usia balita. atau memerlukan bantuan pengasuh tambahan seperti pengasuh anak.

\section{3) Pekerjaan dan Pengasuhan Anak}

Mengenai peran orang tua dalam penanaman moral anak usia dini/prasekolah (studi pada keluarga peran ganda), bahwa ibu cenderung bersifat permissive dan ayah bersifat authoritative. Hal ini disebabkan adanya kesadaran ibu akan terbatasnya waktu bersama anak-anaknya dikarenakan bekerja, sehingga tanpa disadari ibu menerapkan gaya pengasuhan yang longgar.

Pola asuh atau keterampilan parenting pada ibu bekerja dan ibu tidak bekerja, hasil penelitian menunjukkan bahwa tidak ada perbedaan yang signifikan antara ibu bekerja dan ibu tidak bekerja dalam kegiatan parenting. Hasil ini sejalan dengan yang dikemukakan oleh Nomaguchi dan Milkie mengenai sejumlah studi yang menunjukkan tidak adanya perbedaan yang signifikan antara parenting ibu bekerja dan ibu tidak bekerja. Penelitian yang dilakukan oleh Udaranti (2011) mengenai perbedaan keterampilan Parenting pada ayah dan ibu diperoleh kesimpulan bahwa ada perbedaan signifikan pada keterampilan parenting ayah dan ibu, khususnya yang berhubungan dengan pembelajaran tentang peraturan pada anak dan menjaga kesehatan serta keamanan anak.

\section{4) Parenting dan Kewajiban Orang Tua}

Pada umumnya orang tua memang memerlukan pendidikan sebagai upaya untuk pengarahan diri, sehingga mereka mampu mengarahkan diri mereka sendiri dan juga dapat mengarahkan anak-anaknya, karena seringkali orang tua menghambat proses pembelajaran yang dilakukan oleh pendidik. Tidak dipungkiri lagi, bahwa hal ini bisa terjadi sebagai akibat ketidaktahuan orang tua cara mendidik anak yang baik. Padahal 
keterlibatan orang tua dalam lembaga pendidikan anak usia dini sangat penting untuk mewujudkan pembelajaran yang optimal dimasa usia emas anak. Agar orang tua tidak sepenuhnya berharap pada lembaga PAUD saja untuk mendidik anaknya, tetapi kontribusi orang tua juga sangat diperlukan untuk membantu pertumbuhan dan perkembangan anak.

Program parenting yaitu bentuk kegiatan informal yang dilakukan untuk menyelaraskan kegiatan-kegiatan pengasuhan dan pendidikan anak di kelompok bermain dan di rumah. Parenting ini bukan sesuatu yang baru namun juga tidak banyak yang mampu menyelenggarakannya, sehingga penting untuk dikaji dari konsep teoritis tentang manajemen program parenting pada pendidikan anak usia dini, mengingat kegiatan ini sangat bermanfaat dalam membantu pertumbuhan dan perkembangan anak secara maksimal.

\section{5) Smart Parenting}

Pendidikan merupakan proses belajar mengajar yang dapat menghasilkan perubahan tingkah laku. Segera setelah dilahirkan mulai terjadi proses belajar pada diri anak dan hasil yang diperoleh adalah kemampuan menyesuaikan diri dengan lingkungan dan pemenuhan kebutuhan. Pendidikan diselenggarakan dalam bentuk kegiatan belajar mengajar yang dilaksanakan di sekolah atau luar sekolah. Jalur pendidikan sekolah adalah pendidikan yang diselenggarakan di sekolah melalui kegiatan belajar mengajar secara berjenjang dan berkesinambungan, jenjang pendidikan terdiri atas; pendidikan dasar, pendidikan menengah dan pendidikan tinggi. Agar orang tua tidak sepenuhnya berharap pada lembaga PAUD saja untuk mendidik anaknya, tetapi kontribusi orang tua juga sangat diperlukan untuk membantu pertumbuhan dan perkembangan anak.

Program parenting yaitu bentuk kegiatan informal yang dilakukan untuk menyelaraskan kegiatan-kegiatan pengasuhan dan pendidikan anak di kelompok bermain dan di rumah. Parenting ini bukan sesuatu yang baru namun juga tidak banyak yang mampu menyelenggarakannya, sehingga penting untuk dikaji dari konsep teoritis tentang manajemen program parenting pada pendidikan anak usia dini, mengingat kegiatan ini sangat bermanfaat dalam membantu pertumbuhan dan perkembangan anak secara maksimal.

\section{Kesimpulan}

Kesimpulan dari hasil pengabdian ini adalah setelah dilakukan pendampingan selama 6 bulan terhadap pengelola dan guru, PAUD Al Akram sudah memiliki jadwal secara rutin 2 minggu sekali untuk kegiatan parenting kepada orang tua siswa dengan rencana materi-materi parenting yang sudah cukup sistematis dan terstruktur dengan menggunakan pendekatan pembelajaran orang dewasa serta sesuai dengan karakter masyarakat setempat.

\section{Saran}

Diharapkan kepada PAUD Al-Akram untuk dapat melaksanakan Program Parenting secara terjadwal serta materi yang disampaikan secara terstruktur terutama menyangkut 6 aspek perkembangan anak usia dini yang perlu difahami jiga oleh orang tua siswa. Selain itu, diharapkan PAUD Al-Akram menfasilitasi agar adanya pertemuan antara guru dan orang tua secara berkala untuk menyerap informasi seputar perkembangan anak-anaknya. 


\section{Daftar Pustaka}

Amini, M. (2008). Pengasuhan Ayah Ibu yang Patut, Kunci Sukses Mengembangkan Karakter Anak. Yogyakarta: Tiara Wacana.

Gunarsa, Singgih D. (2008). Psikologi Anak: Psikologi Perkembangan Anak dan Remaja. Jakarta: PT BPK Gunung Mulia.

Muhammad Takdir Ilahi, (2013). Quantum Parenting; Kiat Sukses Mengasuh Anak Secara Efektif dan Cerdas, Katahati Jakarta, Cet. I.

Rizka, M. A., \& Tamba, W. (2019). Pelatihan Evaluasi Program Pendidikan Nonformal Bagi Pengelola Pusat Kegiatan Belajar Masyarakat (PKBM) di Kecamatan Gunungsari Kabupaten Lombok Barat. Paradharma (Jurnal Aplikasi IPTEK), 2(1).

Santrock, J. W. (2008). Educational Psychology. 3rd edition. New York: McGraw-Hill Companies.

Santrock, J. W. (2008). Perkembangan Anak. Jilid 1. Erlangga.

Sri, S. N., Rizka, M. A., \& Maskun, M. (2018). Pengaruh Pelatihan Hypnoparenting Terhadap Peningkatan Pemahaman Orang Tua dalam Mendidik Anak Usia Dini di Desa Aikmual Kabupaten Lombok Tengah Tahun 2016. Transformasi: Jurnal Penelitian dan Pengembangan Pendidikan Non Formal Informal, 3(1).

Syaiful Bahri Djamarah. (2004). Pola Komunikasi Orang Tua dan Anak dalam Keluarga, Rineka Cipta Jakarta, Cet.I.

Yani, A., Rizka, M. A., Mataram, P. P. L. S., \& Mataram, F. I. P. IMPLEMENTASI PENDIDIKAN KELUARGA PADA LEMBAGA PENDIDIKAN PONDOK PESANTREN. 